\title{
التقنيات السردية في رواية السفينة لجبرا ابراهيم جبرا
}

\author{
ناهدة أحمد الكسواني \\ أستاذ مشارك- كلية الآداب- جامعة القدس المفتوحة- فلسطين \\ nkiswani@qou.edu
}

DOI: https://doi.org/10.31559/JALLS2020.2.1.1 r.r. تاريخ قبول البحث:r/r

r.r./1/11: تاريخ استلام البحث

حظيت كتابات جبرا إبراهيم جبرا بالكثير من الاهتمام النقدي، وظلت أعماله السردية، على وجه الخصوص، نقطة يتجمع

حولها النقاد والباحثون والمثقفون.

ينصب اهتمامنا في هذا البحث على رواية السفينة لجبرا ابراهيم جبرا، والهدف الذي نسعى إلى تحقيقه من هذا البحث هو

الكشف عن تقنيات السرد في رواية السفينة.

ويركز أيضاً على دراسة خصيائص لغة السرد في السفينة وتناول تشابك الزمان والمكان والحركة الزمكانية في الرواية.

ولعل من أسباب اختيارنا لهذا الموضوع دون غيره، محاولة الكشف عما قد تكتنفه رواية السفينة من جماليات وفنيات سردية

مدهشة

الكلمات المفتاحية: السرد؛ التقنيات السردية؛ المكان؛ الزمن؛ الزمكانية.

\section{(c) (7)}

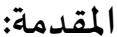

كانت الرواية العربية ولا تزال في بحث مستمر عن تقنيات وأساليب جديدة تضفي عليها جمالية سردية .والحديث عن جمالية

السرد،هو بحث في جماليات المكان وجمالية الشخصيات وجماليات الزمن .

وتكمن أهمية هذه الدراسة في كونها تسلط الضوء على بلى طريقة الاشتغال على السرد وجمالياته في رواية السفينة للأديب

الفلسطيني جبرا إبراهيم جبرا ، الذي تميز بمحاولة البحث عن أسلوب حداثي في كتابة الرواية مع نكهة عربية بشكل عام وفلسطينية

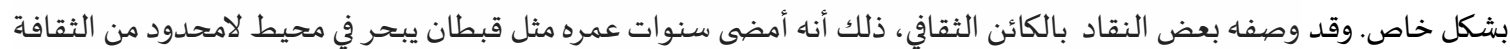

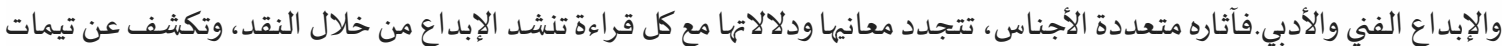
جديدة، وتستقبل إشارات لم تلتقطها قراءات سابقة، لا سيما تلك التي جرت وهو على قيد الحياة. وتتمحور إشكالية هذه الدراسـة في البحث عن إجابة للتساؤلات التالية:

ما المقصود بمصطلح البنية السردية؟ وأين تكمن جماليات السرد في رواية " السفينة " ؟ وإلى أي مدى وفق جبرا في

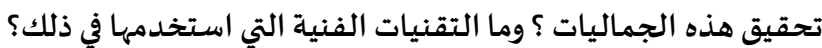

أولاً: مفهوم البنية السردية:

يُعدّ السرد وسيلة جبارة في نسج الأحداث الواقعية والمتخيلة وإعادة تكييفها وتوزيعها في ثنايا النص الروائي، وتمثيل المرجعيات

الثقافية، والتعبير عن الرؤى والمواقف الرمزية.

ولعل أحد أكثر الموضوعات المثيرة للجدل في أوساط المتخصويصين بالدراسات السردية هو: الكيفية التي تتشكل بها المادة السردية، وطرائق تركيهها، وأسـاليب السرد، ثم الرؤى والمنظورات التي من خلاها تنبثق كل عناصر البناء الفني، وأخيرا الإحالات التمثيلية

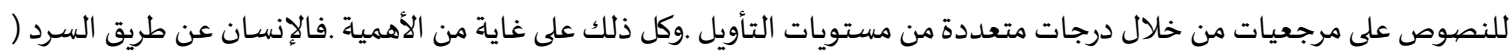

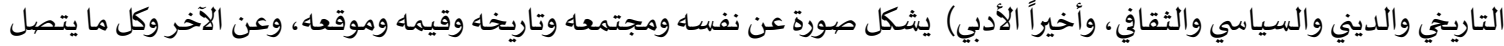

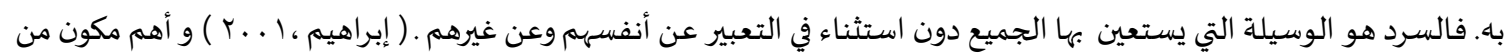


مكونات النص الروائي، كما يعتبر من أولى الأدوات التي يستخدمها الروائي لتحميل النصوص بالمضامين والدلالات. وهو من أكثر

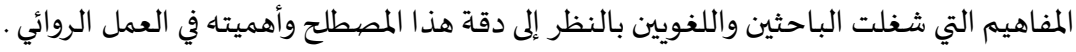

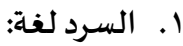

وردت كلمة السرد بمعنى النسج والسبك فهو":الخرز في الأديم بالكسر والثقب كالتسريد فههما، ونسج الدرع، اسم جامع للدروع

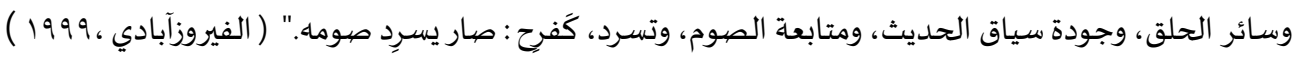

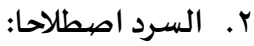

تعددت تعريفات السرد عند النقاد، إذ يرى جيرار جنيت أن السرد هو نقل الحكاية إلى المتلقي" فالمحكي خطاب شفوي أو الو المالي

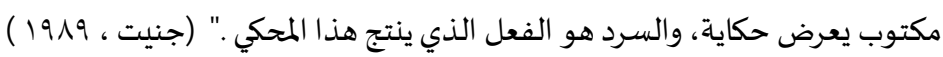

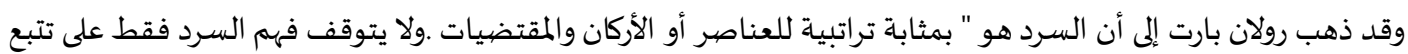

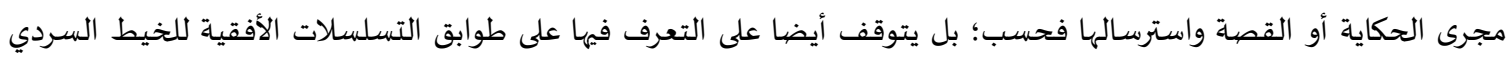

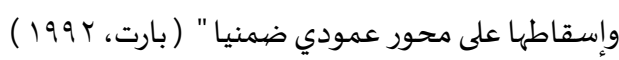
وأشار تودوروف إلى وجود نمطين رئيسيين للسرد يتقاسمان الحضور في النصوص السردية وهما: العرض والحكي مؤكدا أن أن النيا

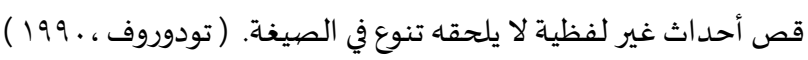
وللسرد حسب سعيد يقطين مفهومان هما:

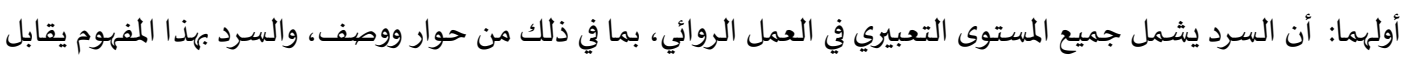

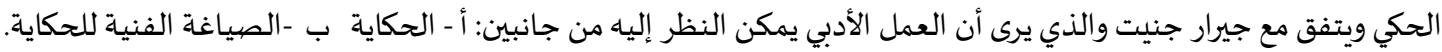

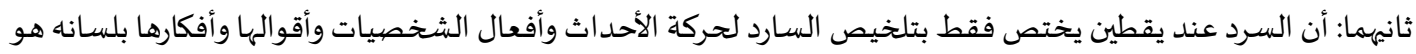

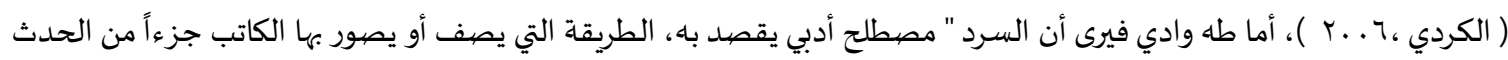

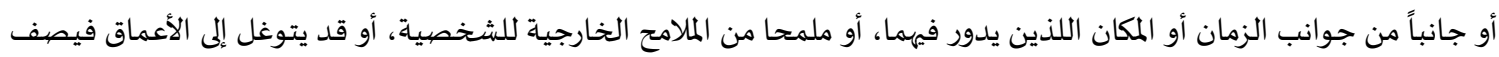

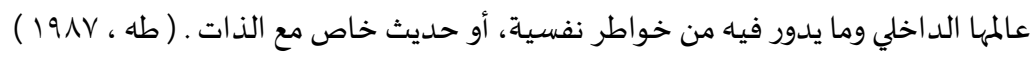

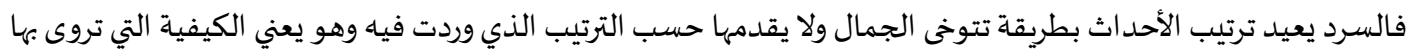

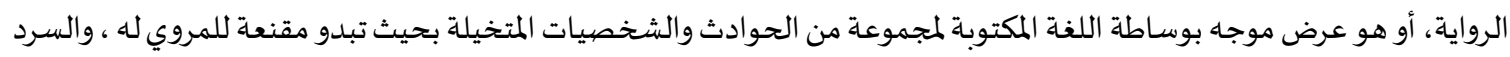

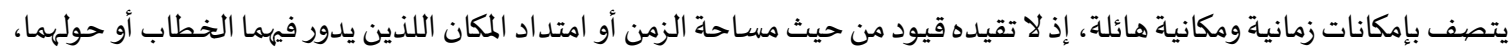

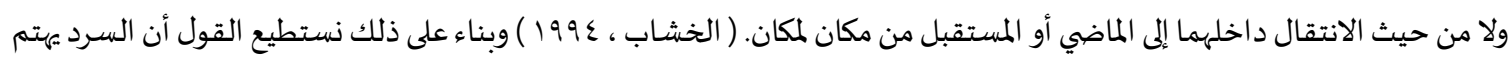

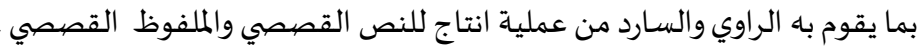

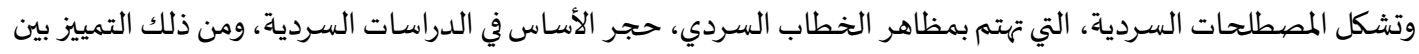
السرد بمعناه العام والخاص، وهيتم المعنى الخاص بجعل النص سردا يتميز عن الحوار والوصف، أما المعنى العام فهيتم بالتقنيات التي

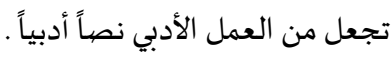
ولما كان الفعل السردي فعلاً تواصلياً فإن البنية السردية لمنجز حكائي ما لا تتشكل إلا بتضافر العناصر المككونة الثلاث التي هي:

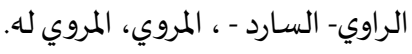
ثانياً: تقنيات السرد في السفينة:

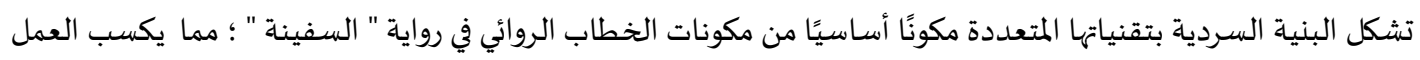

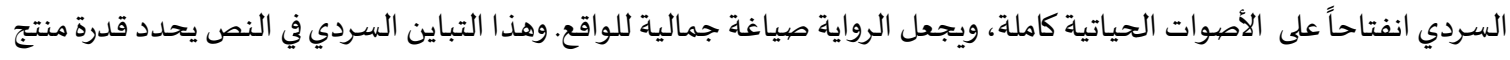

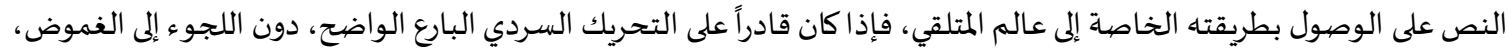

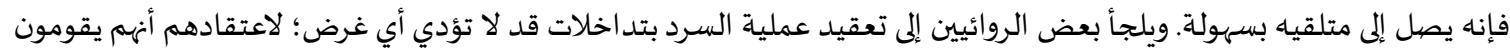

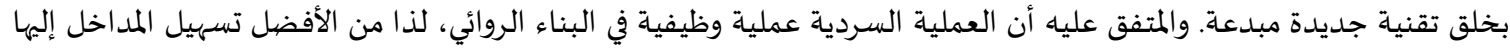

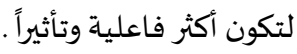

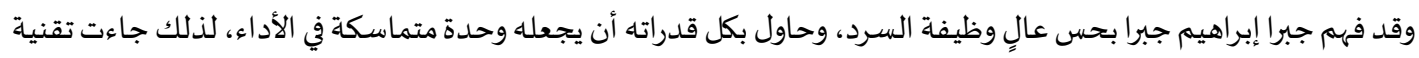

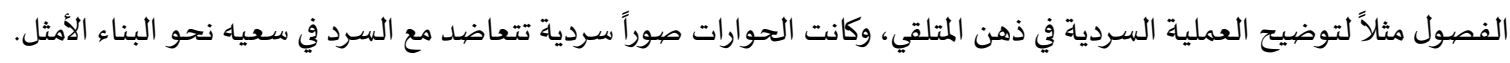

(حسين ، 1999 ) 
فالمتأمل لحقبقة السرد في السفينة يجد أنه قد تداخلت في السفينة العديد من الأساليب السردية، إذ يلجأ إلى جانب ضمير

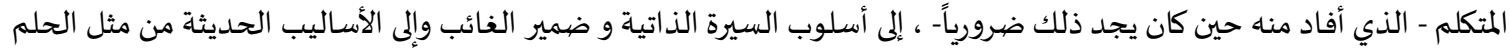

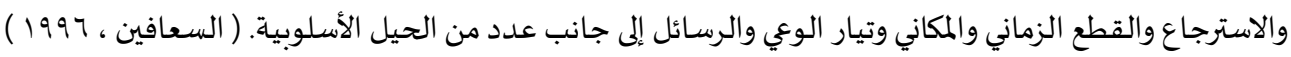

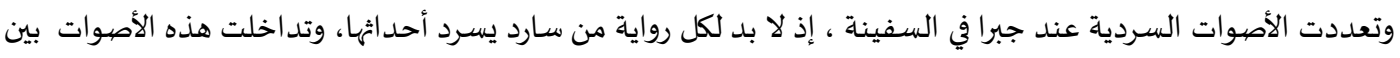

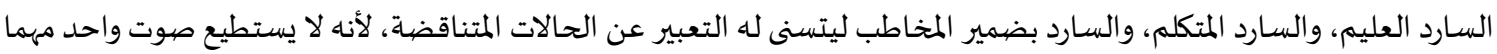

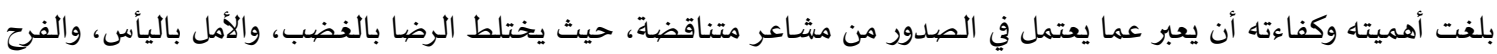

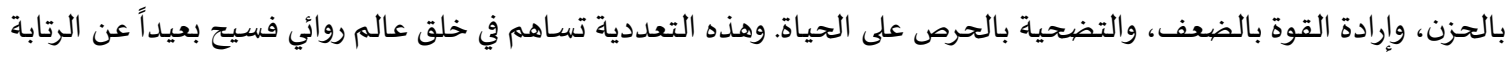

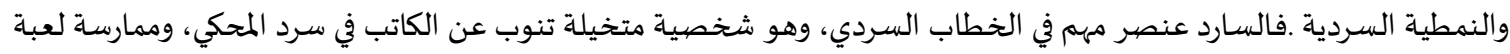
الإههام بواقعية ما يجري، وتمرير أفكاره.

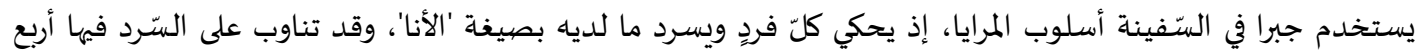

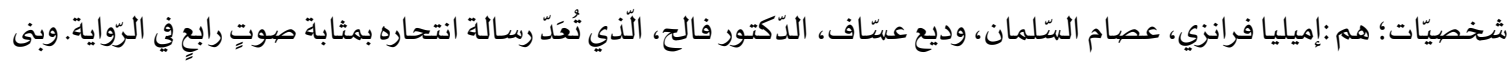

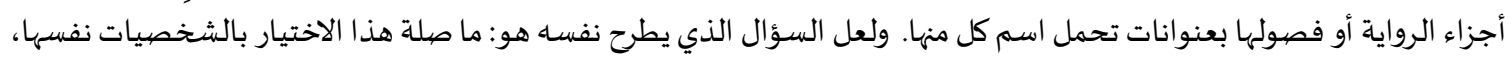

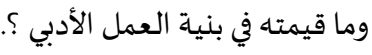

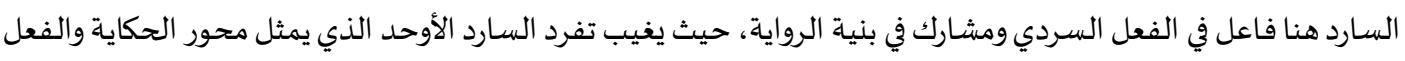

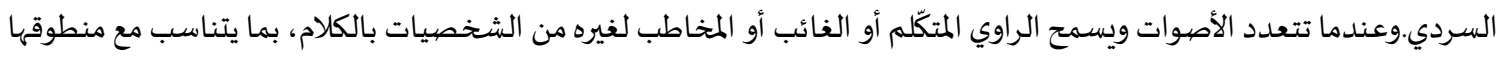

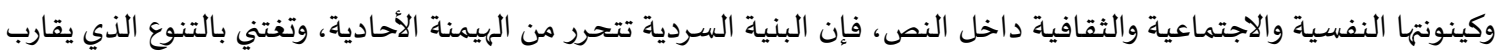

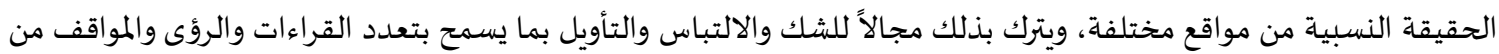

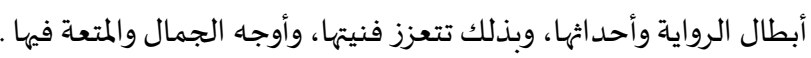

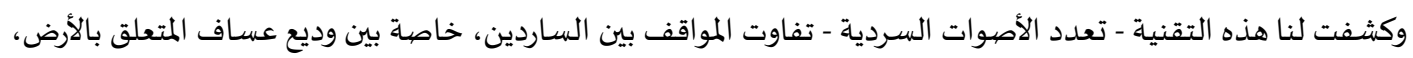

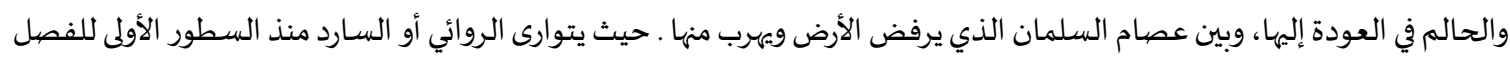

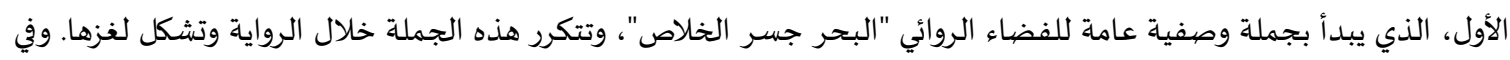

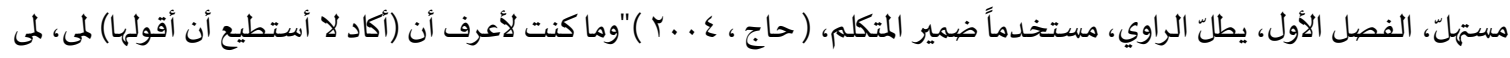

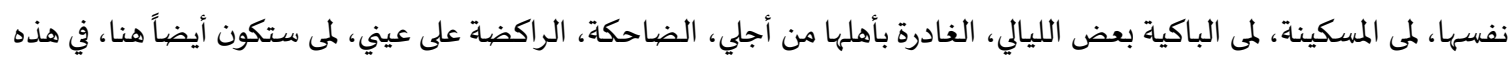

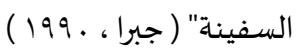

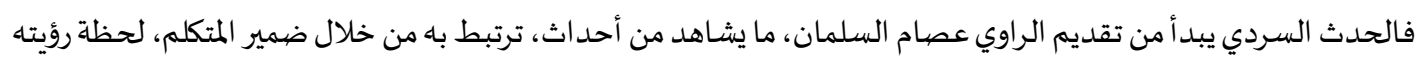

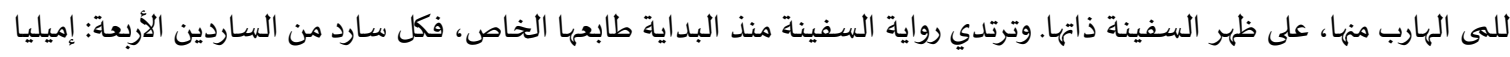

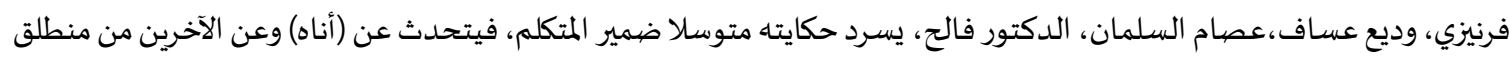

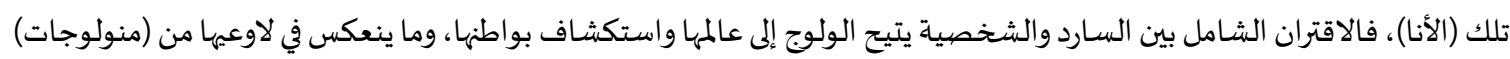

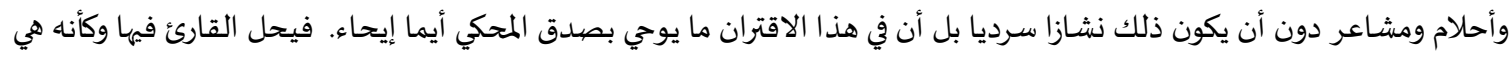

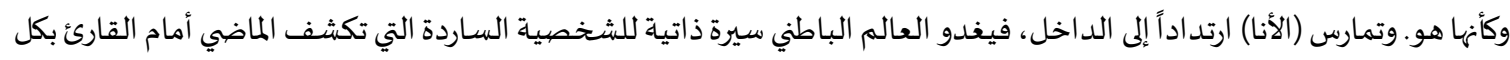

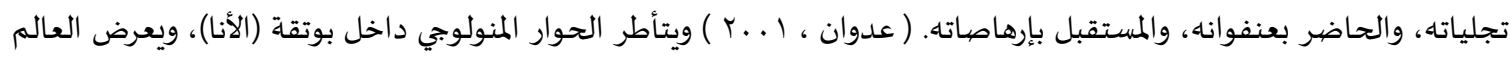

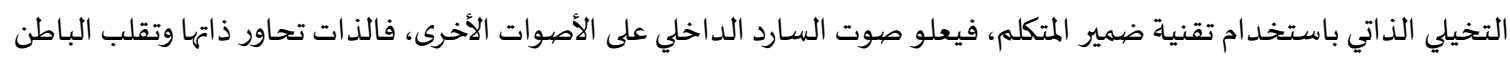

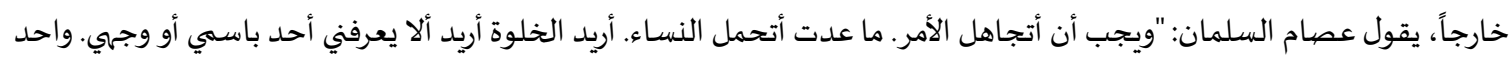

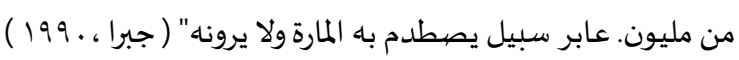

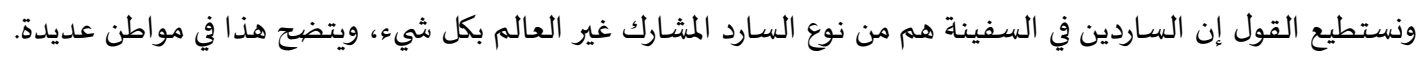

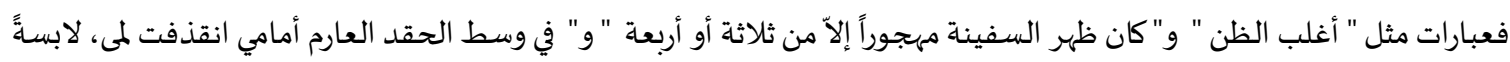

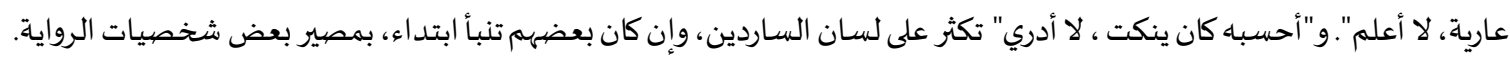

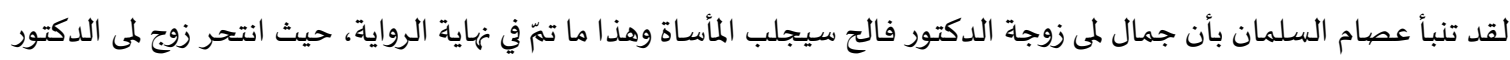

فالح. وأرى أن ذلك النوع من السارد غير العليم له ما يبرره على صعيد النص الروائي؛ إذ يصبح حضوره مقنعاً أكثر من حضوره على الى شكل آخر من السرد . 
وكما ذكرنا سابقاً الساردون أربعة لكن رواية السفينة تدور حول سيرتين شخصيتين هما سيرة عصام السلمان، المهندس العراقي

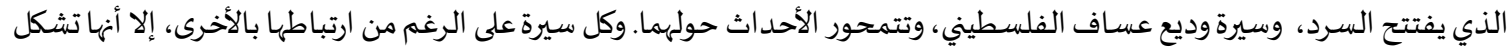

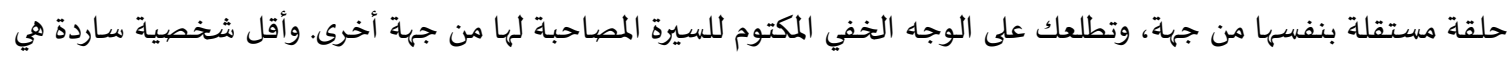

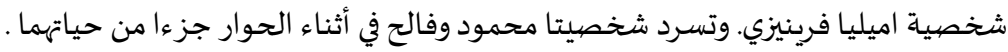

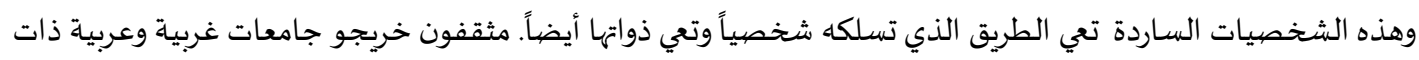

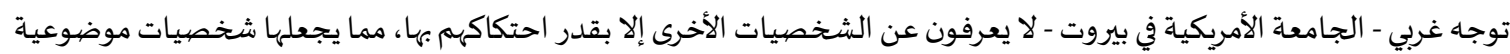

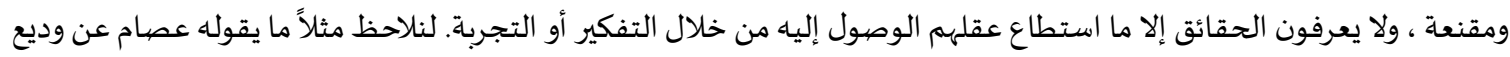

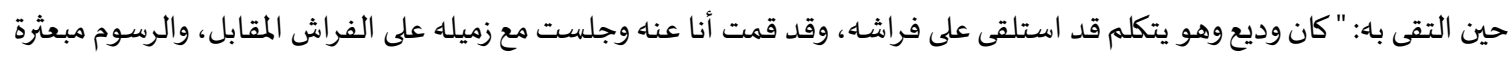

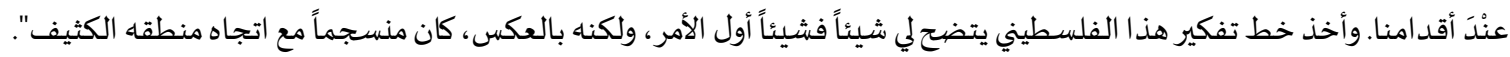

( جبرا ، ـ (199)

ولو حاولنا تتبع السرد في فصول الرواية، نجد أنها في فصول عصام السليمان يتنوع السرد، ففي فصل عصام الأول يبدأ بالسرد

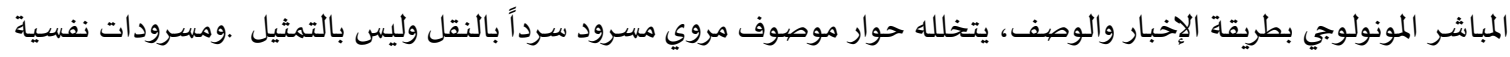

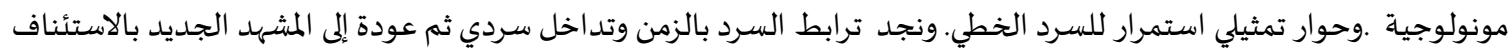

وفي الفصل الثاني لعصام ، الفصل الثالث في النص السردي الكلي: الافتتاحية مقدمة سردية ثم انتقال إلى الحوار المونولوجي

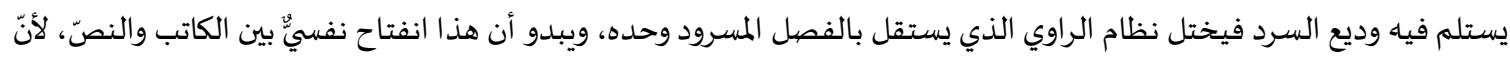

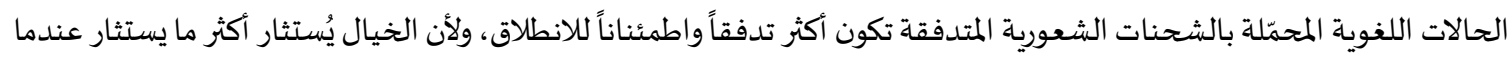

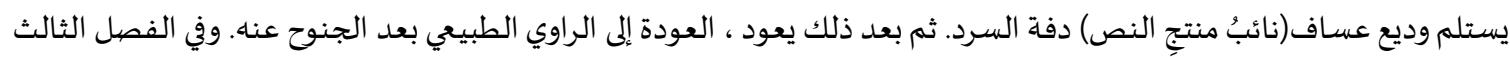

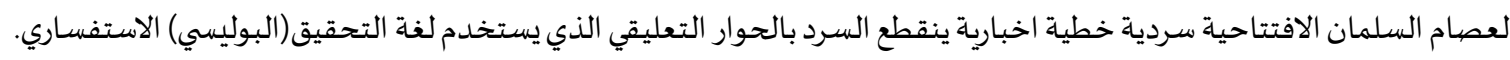

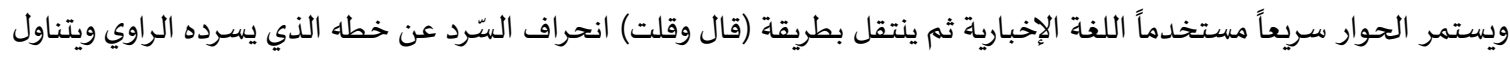

السرد راوٍٍ آخر هو (محمود الراشد) ويسرد قصية داخل عملية الستّرد العامّ.

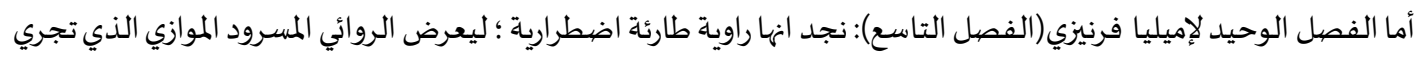

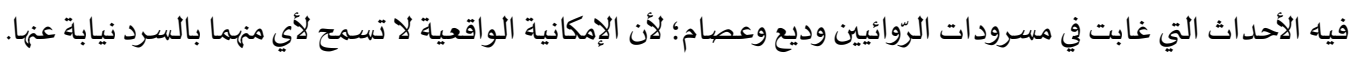

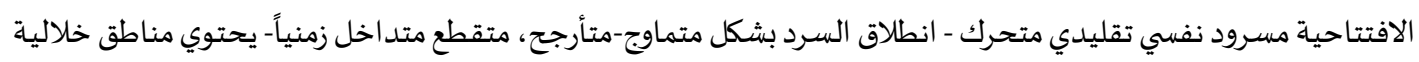

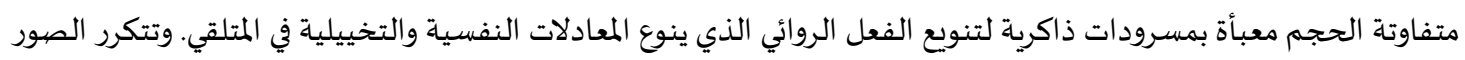

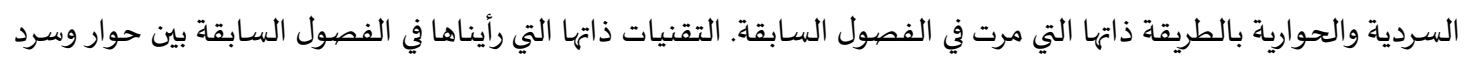

ومقدمات سردية وصفية .

والفصل الأخير في النص يسرده وديع عساف. حيث ينصب الكاتب راويته وديع الحكيم الذي يقطف ثمار الأحداث ونتائجها

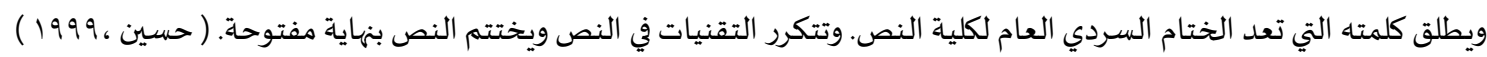
هذا بالنسبة للسرد أما لغة جبرا السردية في السفينة، فتعد وسيلة للوصول إلى الشخصيات فهي تتميز بتنوعها ومناسبتها

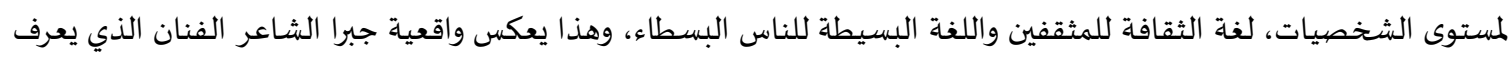

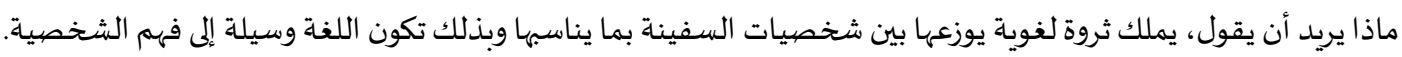

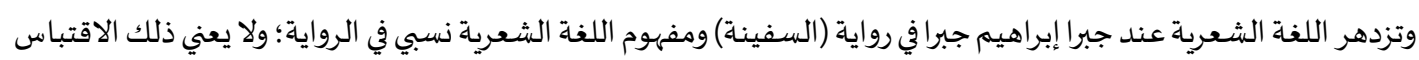

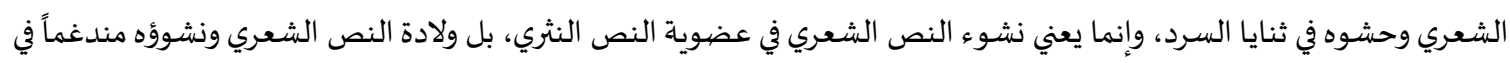

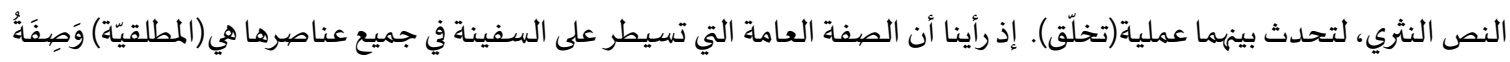

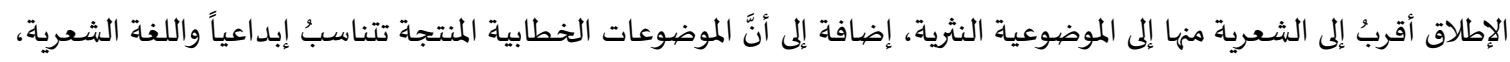

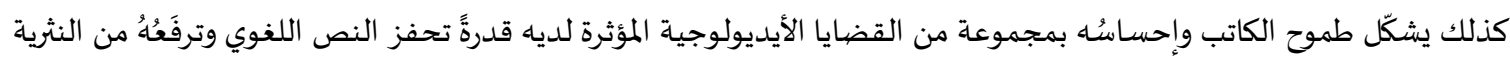

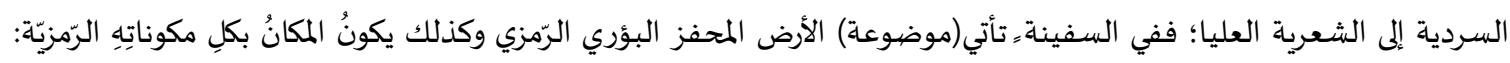

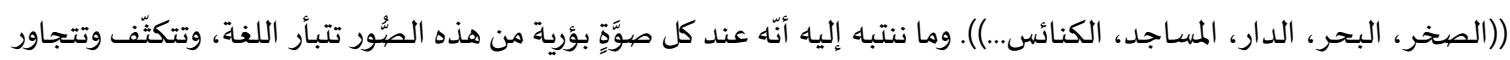

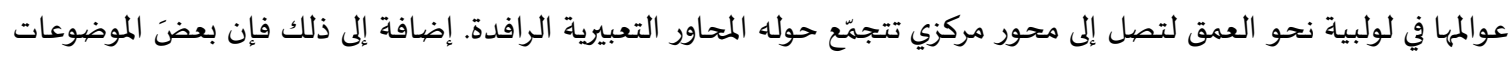
الخطابية كالحبّ والجنس والأنثى، وبعض القضايا الأيديولوجية والفكرية تبعث على توتر اللغة وارتقائها. ( حسين ، 


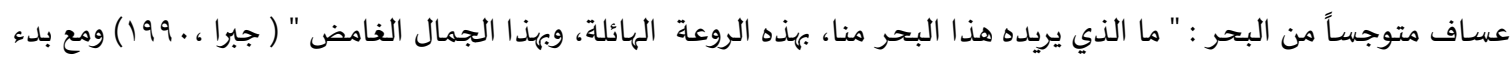

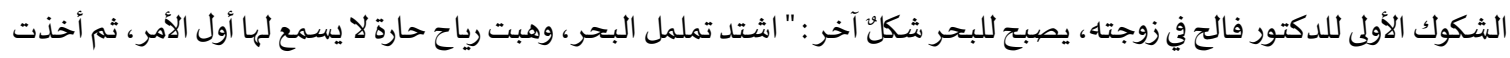

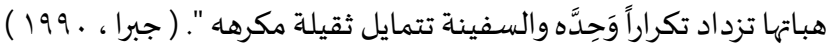

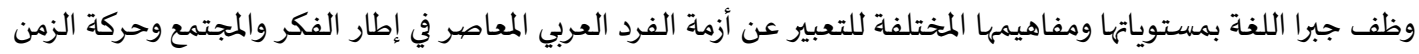

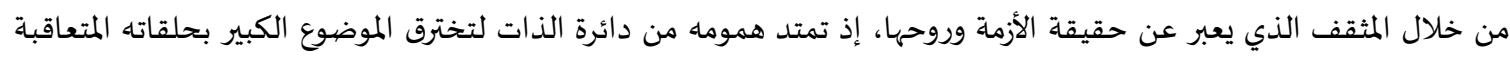

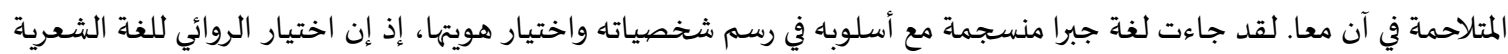

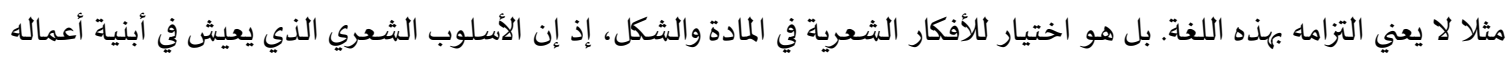

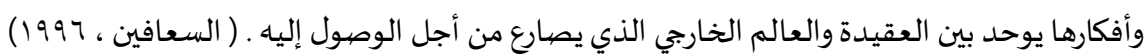

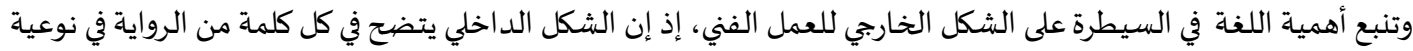
هذا الكلام وفي بناء الكلام والصور والأفكار وهو في النهاية الذي يقوم بدور حاسم بين الظاهر والخفي . ( تشيتشرين ، ـ لـ191 )

ثالثاً : المكان والزمان في السفينة ( الزمكانية ) 1. جدلية العلاقة بين الزمن والمكان السرديين يشكل الزمن والمكان بعدين مهمين في الأدب، لكونهما نسقين وجوديين تتكامل التجربة الإنسانية فهيما وبهما. وقد شاع في

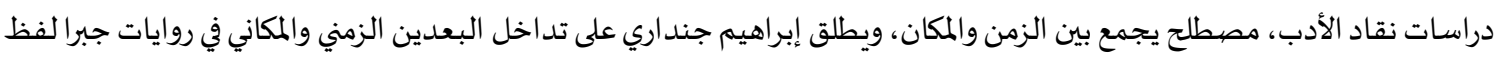

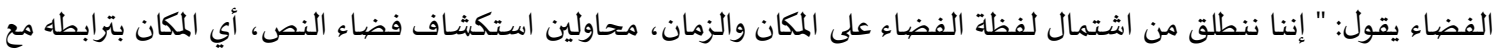

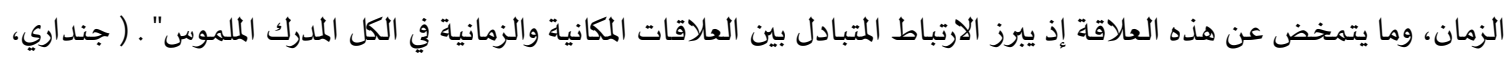

وإن الحديث عن الزمن والمكان في بنية السرد يقتضي التأكيد دوماً على العلاقة التي تربط بينهما، كما أن دراسة كل منهما

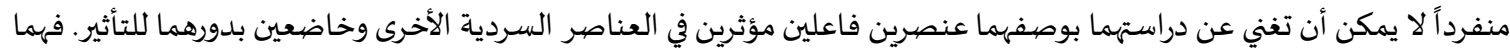

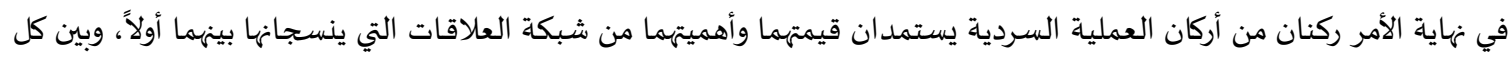

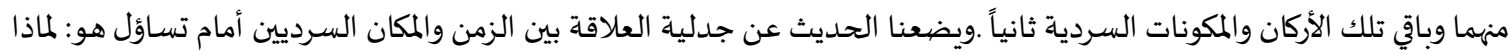

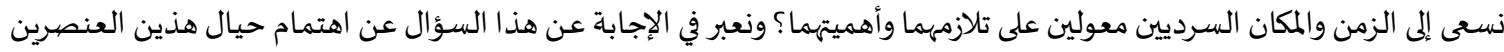

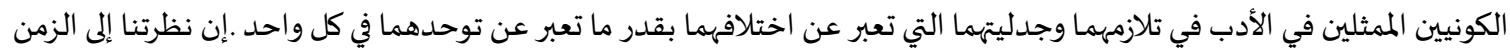

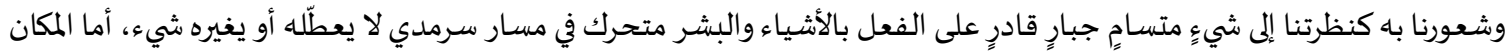
فهو ثابت لا يتحرك يرى ويلمس ويفعل به من قبل الزمن، ومع ذلك فالزمن مفتقر إليه ليرسل من خلادلاله إلينا دلائل وعلامات اليات وجوده.

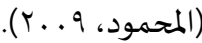

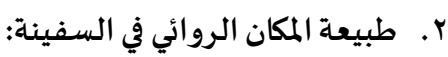

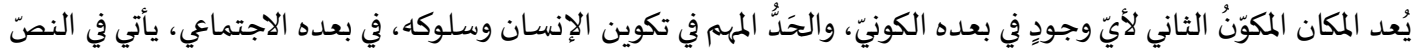

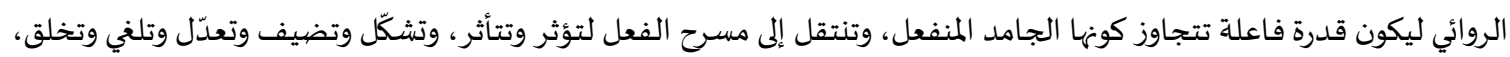

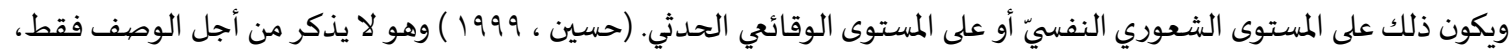

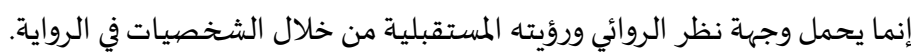
ويشكل المكان في رواية السفينة عنصراً مهما من عناصر الرواية ، وهو بمثابة الشخصية الرئيسة التئية التئية تربط مختلف شخصيات الرواية وعلاقاتهم وأهد افهم ومصيرهم فقد جسدت السفينة وهي مكان تجمع شخصيات الرواية، نقطة الانطلاق نحو المجههول إنها

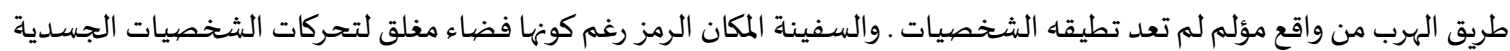

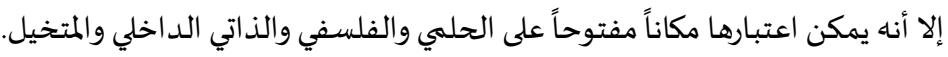
وتعد السفينة (المكان الرمز)، إذ يبئر النص الدلالة المكانية في العنوان وهو المكان المقلق الذي يبحث عن الاستقرار وهو في ذلك الكالك الماني

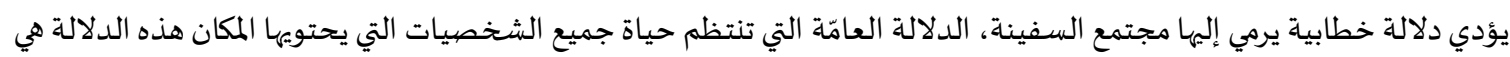

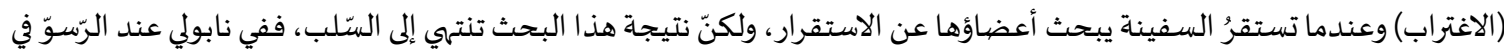

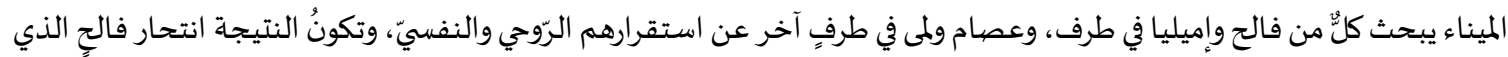

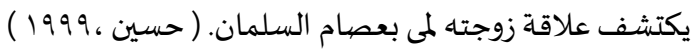


وقد دعم اختيار السفينة، كمكان الدلالة البنائية للرواية، إذ ساعد ذلك على تصوير تطور الزمن السردي داخل الرواية،

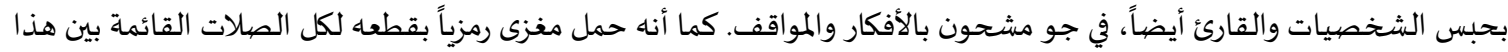

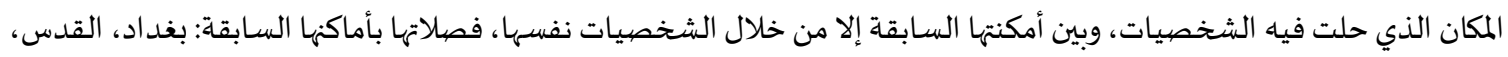

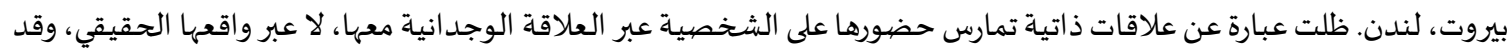

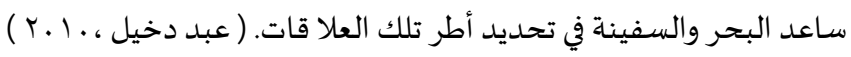

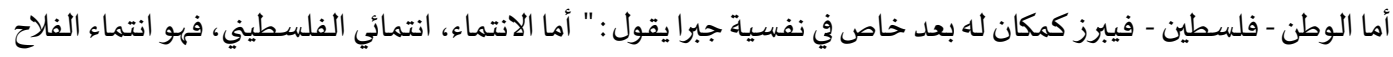

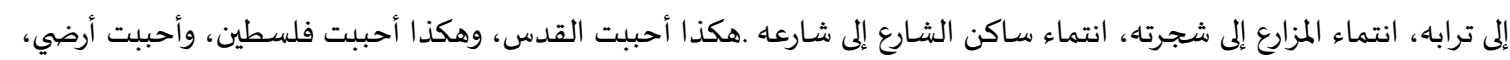

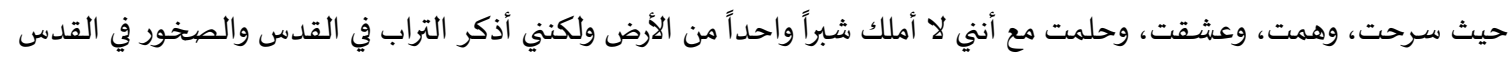

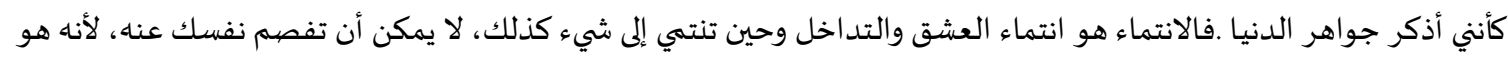

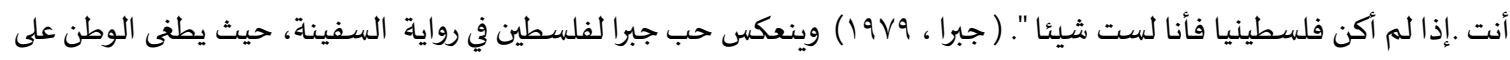

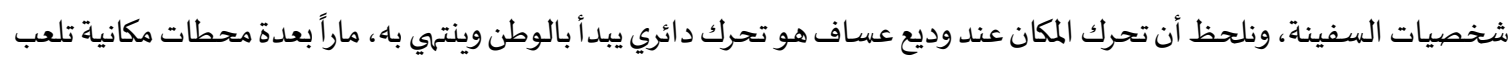

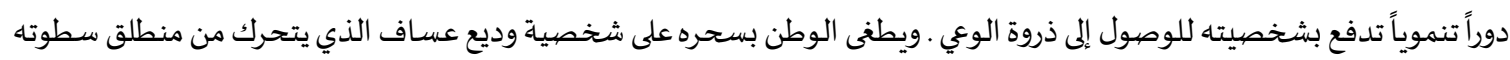

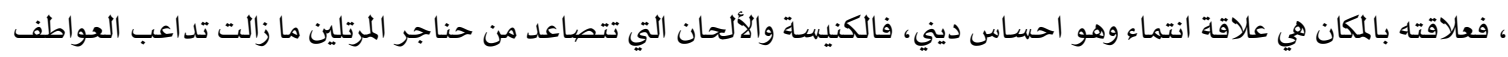

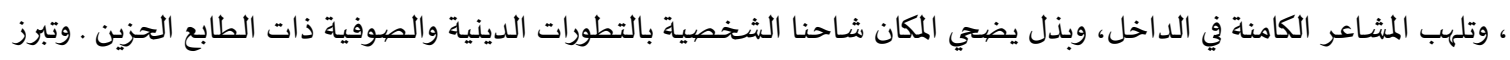

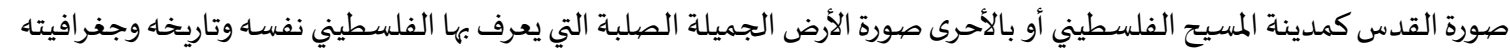

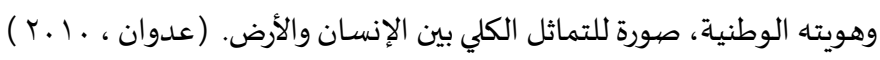

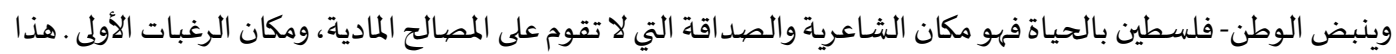

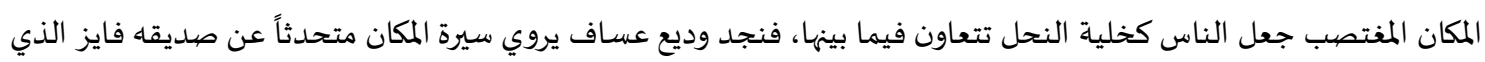

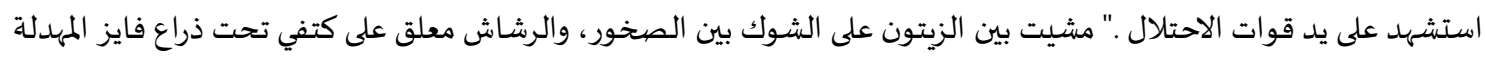

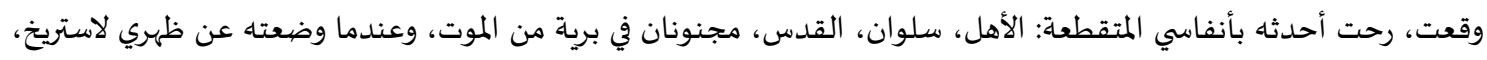

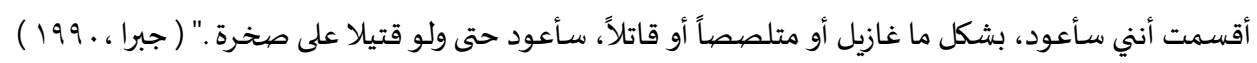

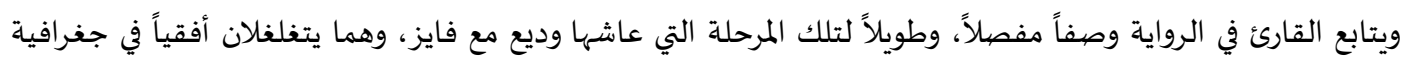

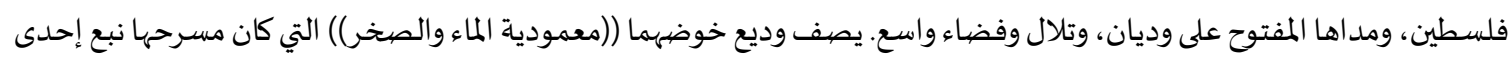

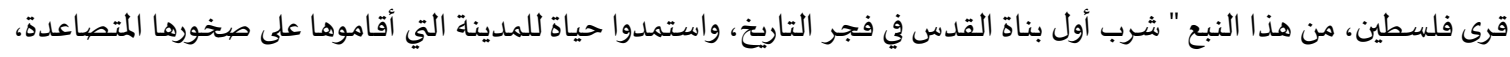

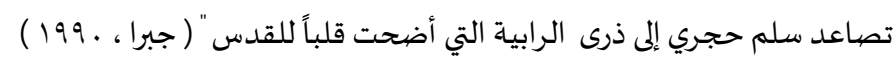

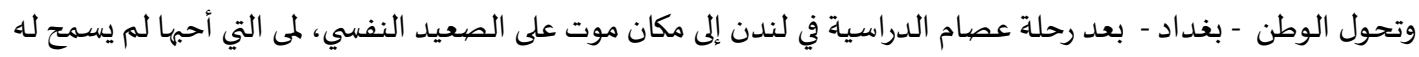

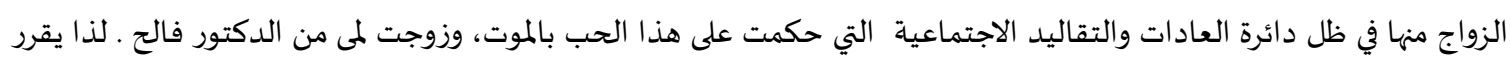

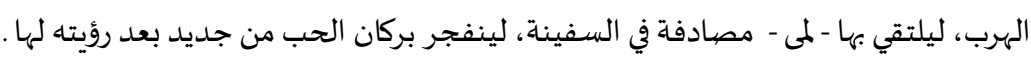

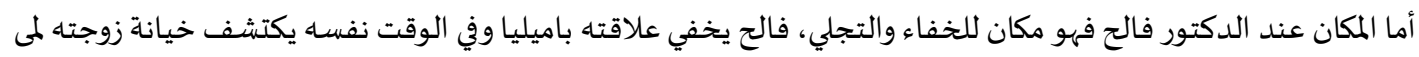

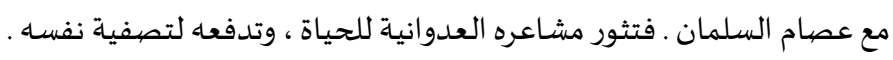

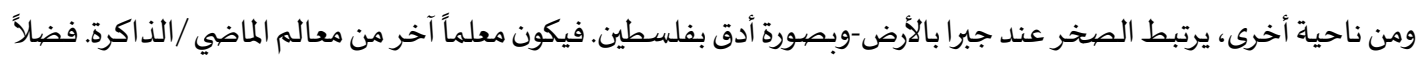

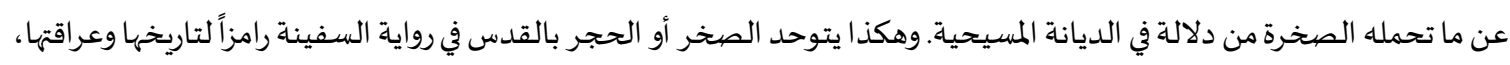

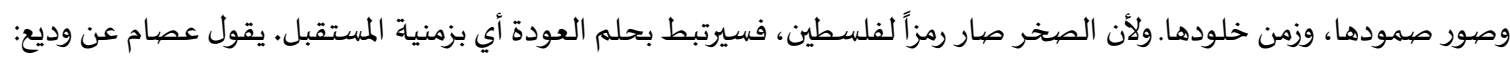

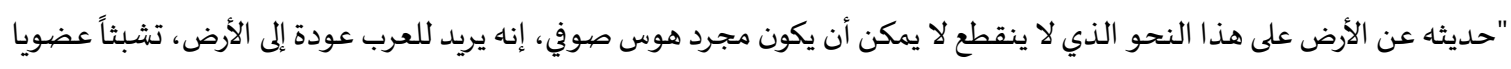

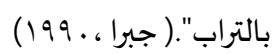

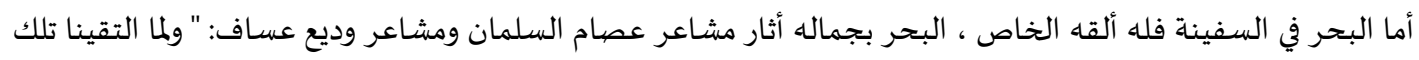

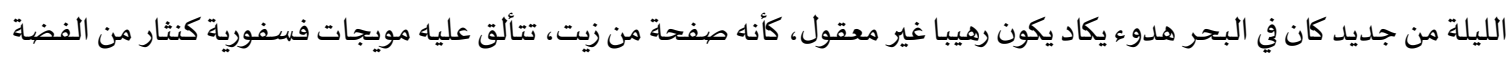

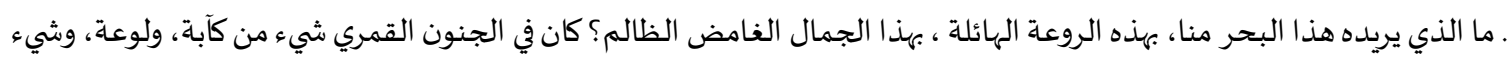

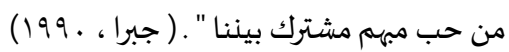


زمن السفينة (مستويات النص الزمني ):

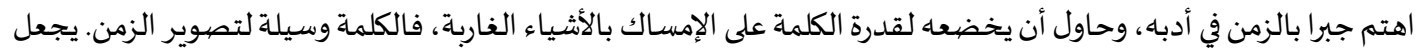

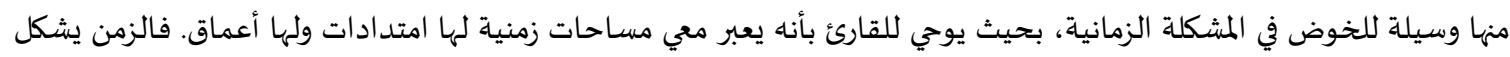

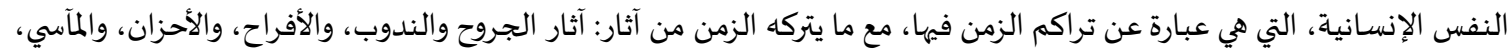

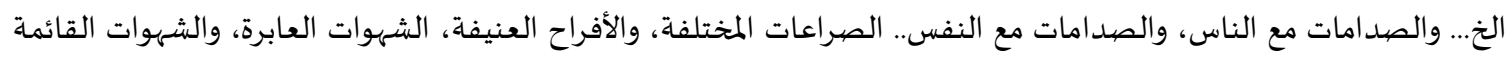

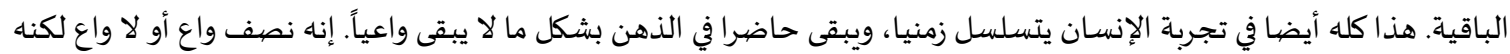

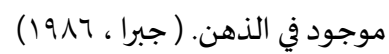

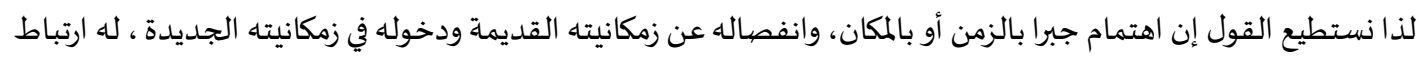

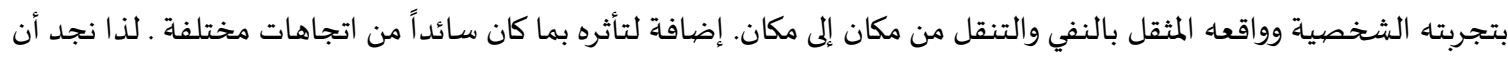

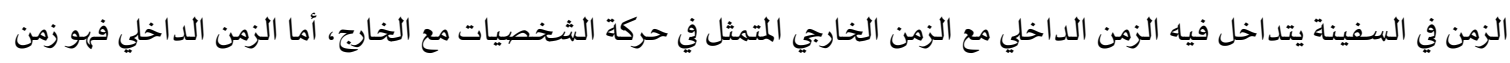

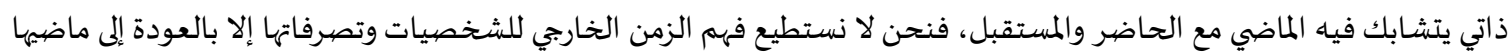

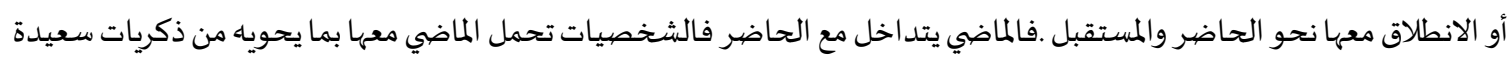

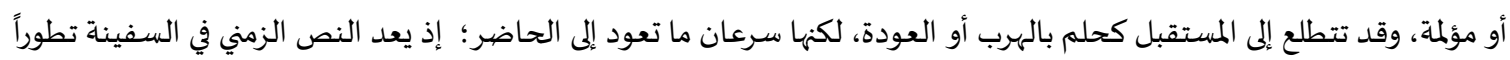

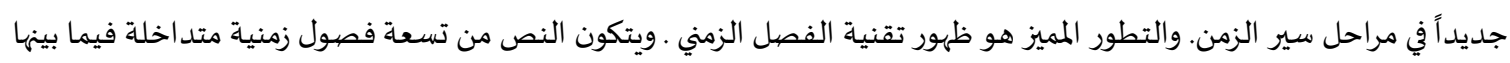

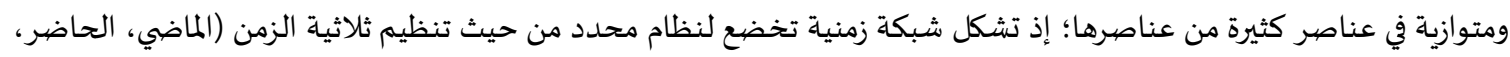

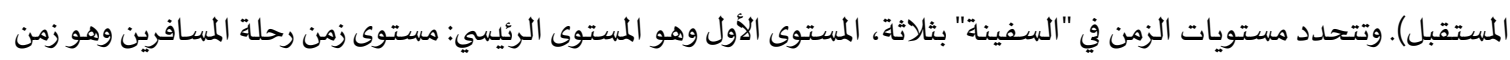

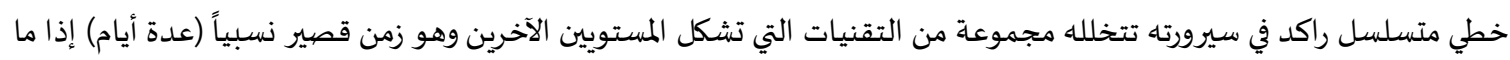

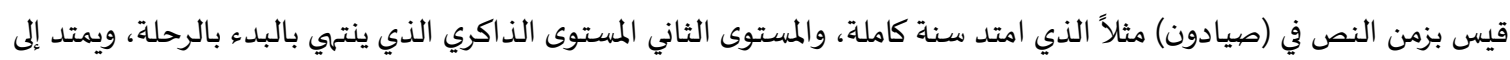

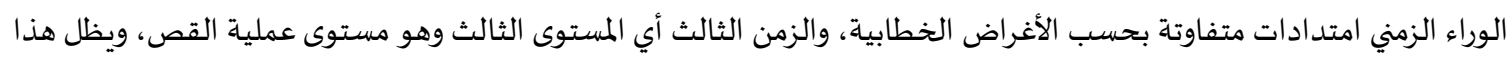

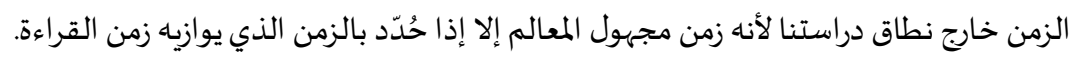

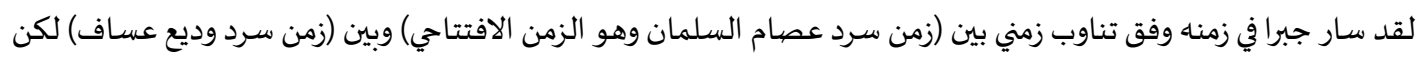

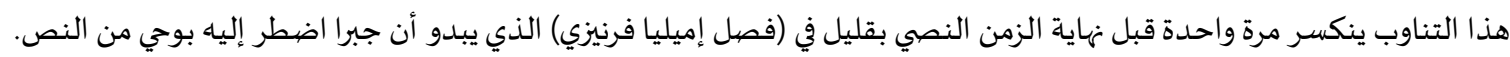

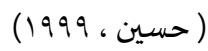

فالسفينة هي حاضر كل الشخصيات أي ان تجمع كل هذه الشخصيات للرحلة هو بداية زمن الرواية من نقطة الحاضر ثم

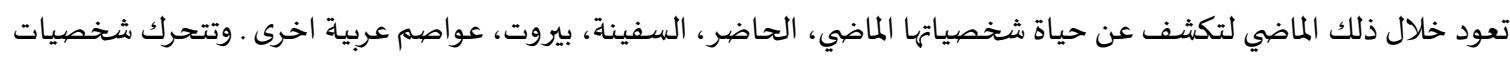

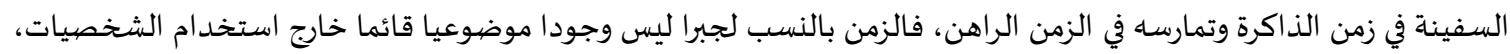

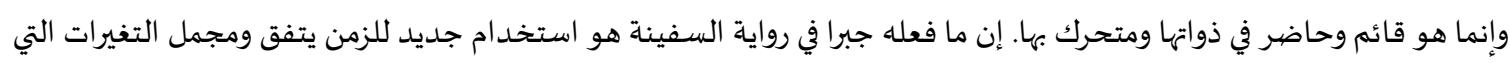

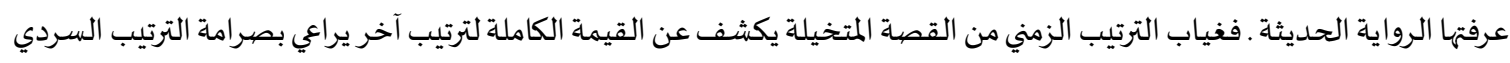

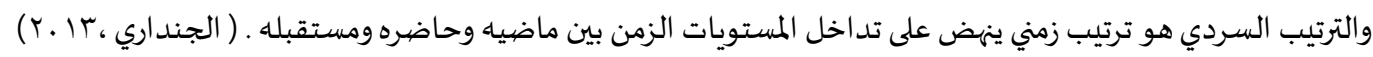

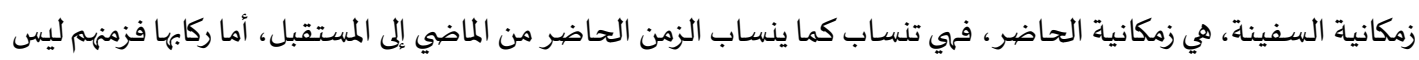

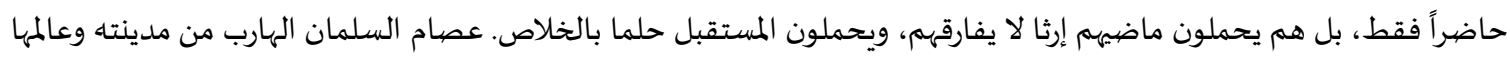

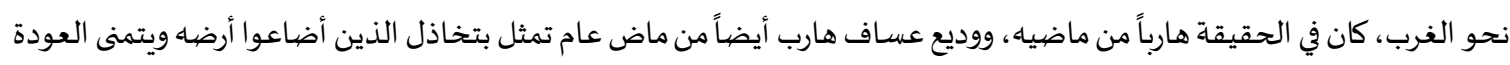

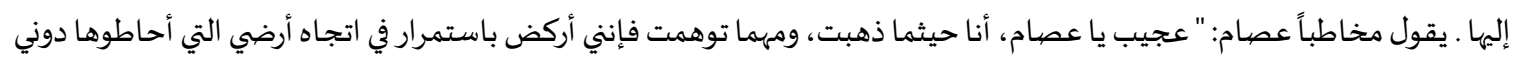

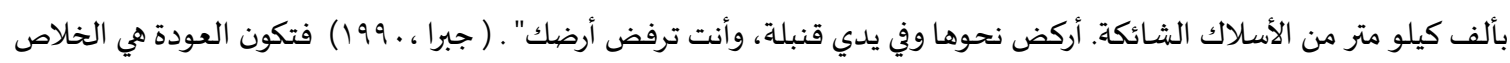

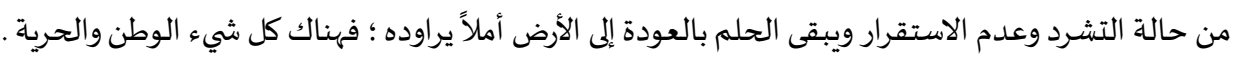

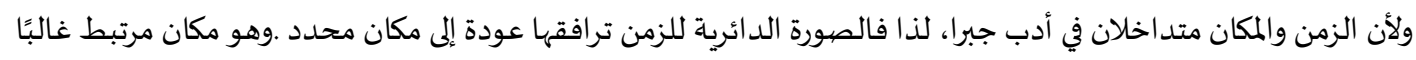

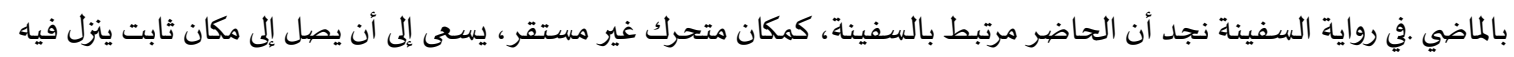

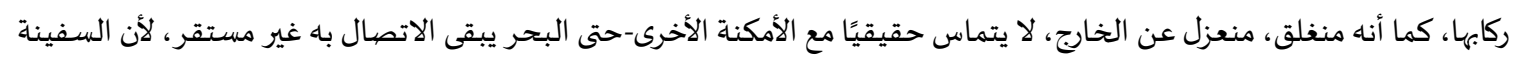
تتحرك باستمرار. 
وقد دعم اختيار السفينة، كمكان، الدلالة البنائية للرواية؛ إذ ساعد ذلك على تصيوير تطور الزمن السردي داخل الرواية،

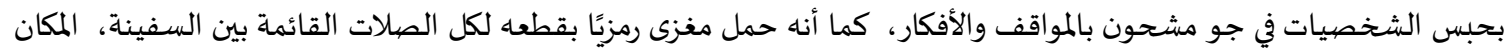

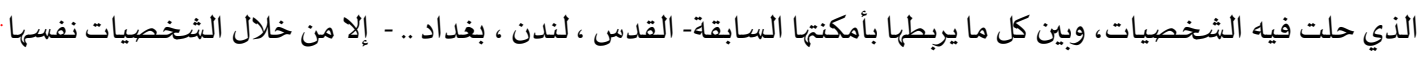

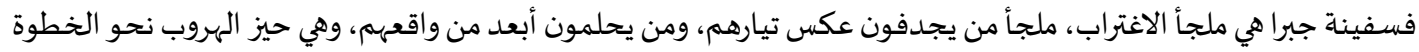

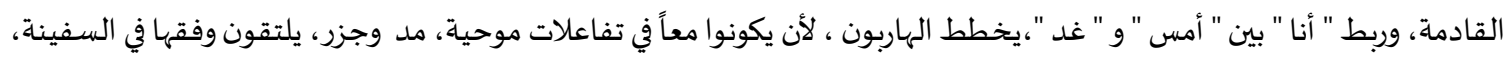

ليعيشوا البحر الوجودي بكل تقلباته وتناقضاته، يعيشون رحلة البحر الذي يتفاعل معهم كما تتفاعل الأحداث ـ ( عودة ، ع . . ج) )

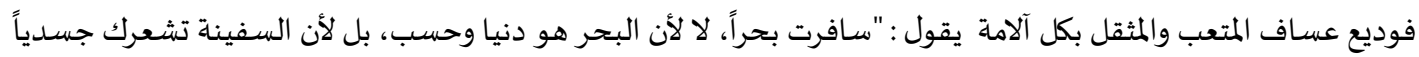

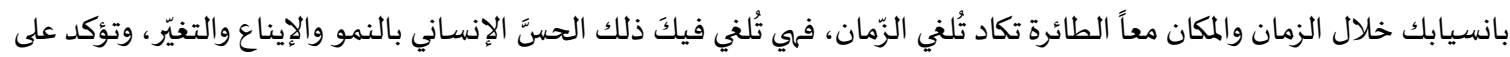

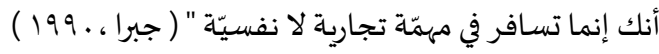

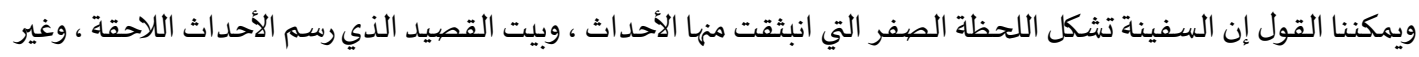

إيقاع تحرك الشخصيات، وهنا يتداخل الزمن بالمكان ( الزمكانية )

الخاتمة:

توصلت هذه الدراسة إلى مجموعة من النتائج يمكن إجمالها فيما يأتي:

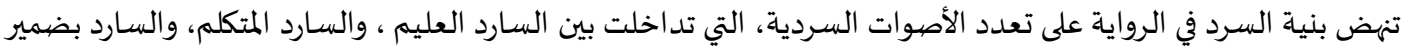

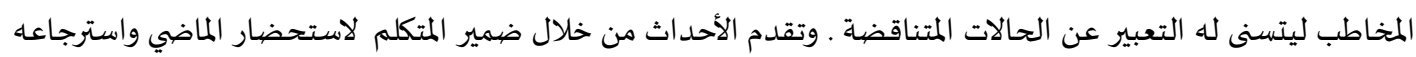

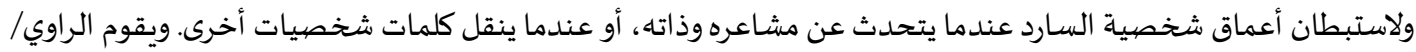

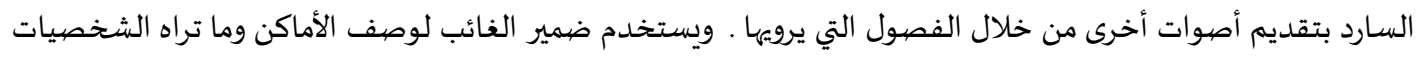
وتسمعهد. هيتولى السلمان ووديع وإميليا والدكتور فالح، سرد تفاصيل الحكاية السردية، فالسارد هنا فاعل في الفعل السردي ومشارك في

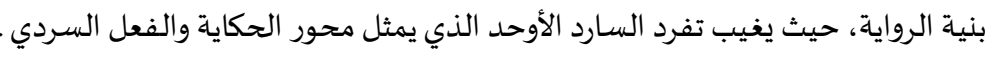

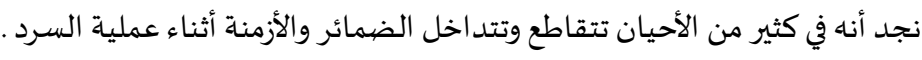
الزمان والمكان، شكلا حضورا لافتا في السفينة، عاكساً تواشج علاقة الذات بأزمنتها وأمكنتها المختلفة في رحلة اكتمالها، ونضج

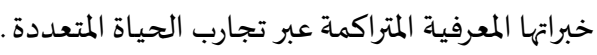
تزدهر اللغة الشعرية عند جبرا إبراهيم جبرا في رواية (السفينة)

1. إبراهيم،ع ، (1 . . ) السرد والتمثيل السردي في الرواية العربية المعاصرة - بحث في تقنيات السرد ووظائفهـ ، جامعة قطر .

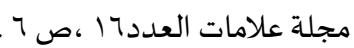

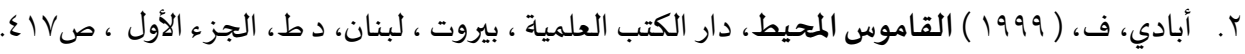

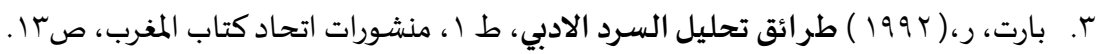

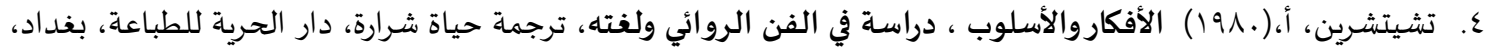
ص. 71 . 71.0

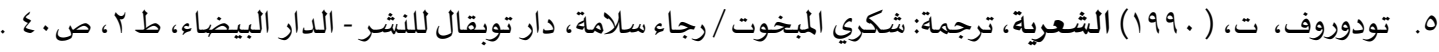

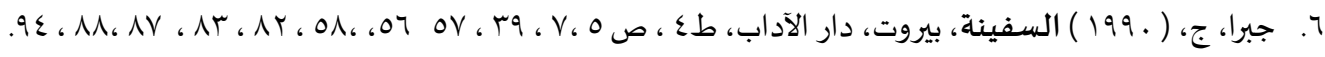

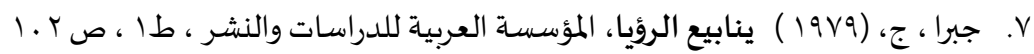

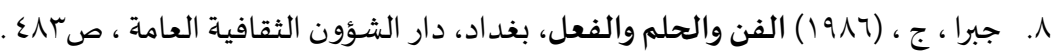

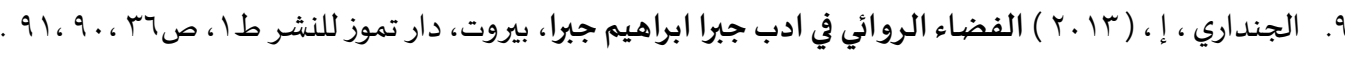

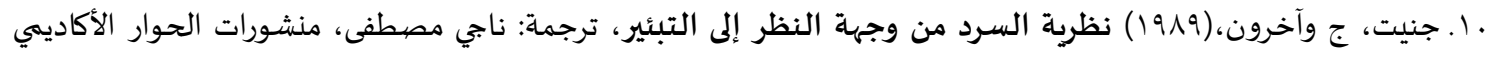

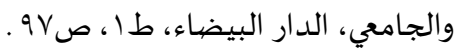




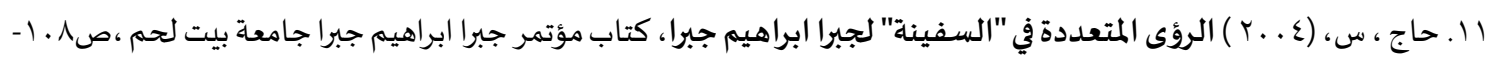
.1 .9

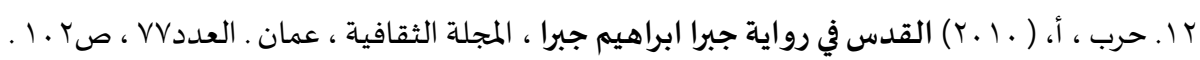

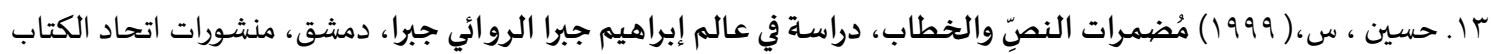

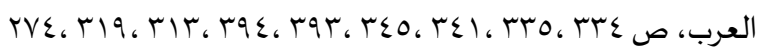

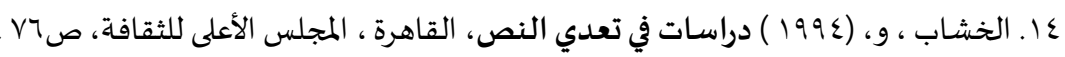

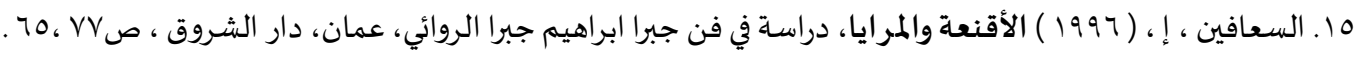

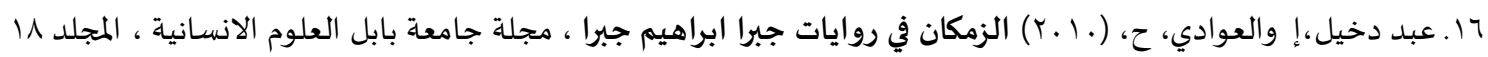

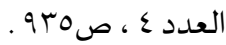

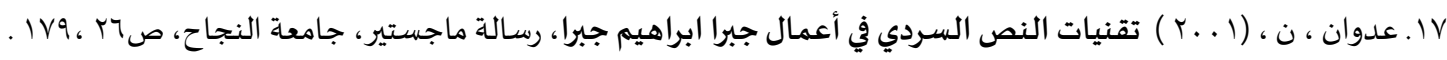

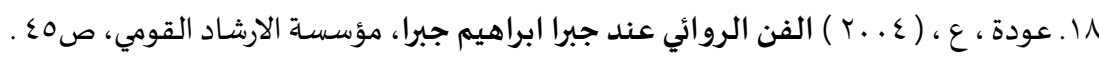

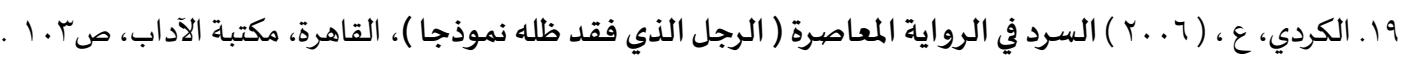

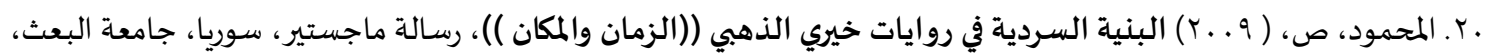

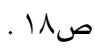

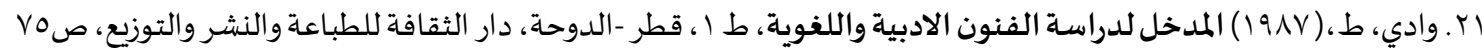




\title{
The Narrative Techniques in the Novel of the Ship for Jabra Ibrahim Jabra
}

\author{
Naheda Ahmad EL-Kiswani \\ Associate Professor, Al-Quds Open University, Palestine \\ nkiswani@qou.edu
}

Received Date : $11 / 1 / 2020$

Accepted Date : $2 / 3 / 2020$

DOI : https://doi.org/10.31559/JALLS2020.2.1.1

Abstract: The writings of Jabra Ibrahim Jabra received a lot of critical attention, and his narrative work, in particular, remained to be an important thing to critics, researchers and intellectuals.

In this study we focus mainly on the novel "The Ship" of Jabra Ibrahim Jabra, and the goal we seek to achieve from this research is to reveal the techniques of narration in this novel.

It also focuses on the study of the characteristics of narrative language in the ship and on the interplay of time, space and spatial mobility in the novel.

And trying to compete in this creative world based on the method of "descriptive/ analytical" research to seek the nature of narrative structure of Jabra.

\section{Keywords: Narration; Narrative techniques; the place; Time; Chronotope (Elzimkanah).}

\section{References:}

[1] 'bd Dkhyl. A \& Al'wạdy. H, Alzmkạn Fy Rwạyạt Jbrạ Ạbrạhym Jbrạ, Mjlë Jạm‘̈̈ Bạbl Ạl'lwm Ạlạnsạnyh, 18 (4) (2010), pp. 935 .

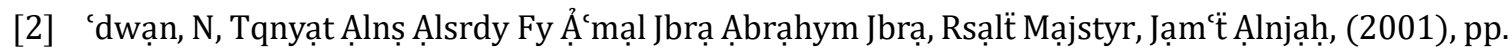
26,179 .

[3] 'wdh. ', Alfn Ạlrwạỷy 'nd Jbrạ Ạbrạhym Jbrạ, Mw̉ssẗ Ạlạrshạd Ạlqwmy, (2004), pp.45.

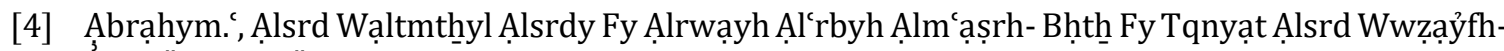
, Jạm‘̈̈ Qțr. Mjl̈̈ 'lạmạt (16) (2001), pp. 6.

[5] Ạ̉bạdy. F, Ạlqạmws Ạlmhyț, Dạr Ạlktb Ạl'lmyh, Byrwt, Lbnạn, D Ṭ, Ạljz’ Ạlạ̉wl, (1999), pp. 417.

[6] Bạrt. R, Trậ̉q Tḥlyl Ạlsrd Ạlạdby, Ṭ 1, Mnshwrạt Ạthạd Ktạb Ạlmghrrb, (1992), pp.13.

[7] Hạj. S, Ạlrw̉y Ạlmt‘ddh Fy "Ạlsfynh" Ljbrạ Ạbrạhym Jbrạ, Ktạb Mw̉tmr Jbrạ Ạbrạhym Jbrạ Jạm‘̋̈ Byt Lhm, (2004), pp. 108-109.

[8] Ḥrb, Ạ, Ạlqds Fy Rwạyẗ Jbrạ Ạbrạhym Jbrạ, Ạlmjlh Ạlth́qạfyh, 'mạn, (77) (2010), pp.102 .

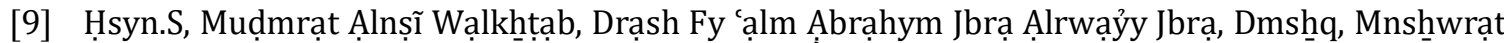
Ạthạd Ạlktạb Ạl'rb, (1999), pp. $334,335,341,345^{3}, 393,394,313,319,274$.

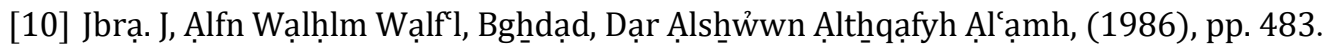

[11] Jbrạ. J, Ạlsfynh, Byrwt, Dạr Ạlậdạb, Ṭ4, (1990), pp. 5 ,7, 39, 57, 56, 58, 82, 83, 87 ,88, 94.

[12] Jbrạ. J, Ynạbyc Ạlrw̉yạ, Ạlmw̉ssh Ạl'rbyh Lldrạsạt Wạlnsḩr, Ṭ1(1979), pp. 102.

[13] Ạljndạry. A, Alfḍạ’ Ạlrwạyy Fy Adb Jbrạ Ạbrạhym Jbrạ, Byrwt, Dạr Tmwz Llnsh̆r, Ṭ1, (2013), pp. $36,90,91^{3}$.

[14] Jnyt. J Wậkhِrwn, Nzryẗ Alsrd Mn Wjhë Ạlnẓr Ala Ạltbỷyr, Trjmë: Nạjy Mșțfa, Mnshwwrạt Ạlḥwạr Ạlạ̉kạdymy Wạljạm y, Ạldạr Ạlbyḍạ’, Ṭ1, (1989), pp. 97.

[15] Ạlkh_shạb. W, Drạsạt Fy T'dy Ạlnṣ, Ạlqạhrh, Ạlmjls Ạlạ̉ly Llthַqạfh, (1994), pp.76.

1. 
[16] Ạlkrdy. ', Ạlsrd Fy Ạlrwạyh Ạlm‘ạșrh Ạlrjl Ạldhyy Fqd Ẓlh Nmwdḥjạ), Ạlqạhrh, Mktbë Ạlậdạb, (2006), pp. 103.

[17] Ạlmḥmwd. Ș, Ạlbnyh Ạlsrdyh Fy Rwạyạt Khyry Ạldḥhby ((Ạlzmạn Wạlmkạn)), Rsạlt Mạjstyr, Swryạ, Jạmë Alb`th, (2009), pp.18.

[18] Ạls‘ạfyn. A, Alạ̉qn`h Wạlmrạaạ, Drạsh Fy Fn Jbrạ Ạbrạhym Jbrạ Ạlrwậyy, 'mạn, Dạr Ạlshrrwq, (1996), pp. 77,65 .

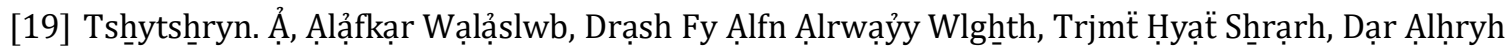
Llțbạ'h, Bghdạd, (1980), pp. 60 ,61.

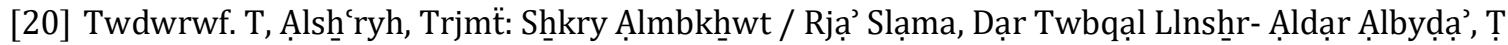
2, (1990), pp.40.

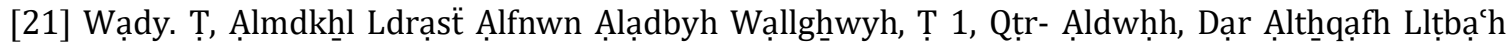
Wạlnshrr Wạltwzyc', (1987), pp.75. 